\title{
HUMAN SECURITY IN THE NIGER DELTA: EXPLORING THE INTERPLAY OF RESOURCE GOVERNANCE, COMMUNITY STRUCTURE AND CONFLICTS
}

\author{
Olayinka Ajala*
}

\begin{abstract}
Prior to August 2009, the Niger Delta region of Nigeria witnessed widespread violent conflicts between the government, multinational oil corporations (MNCs) and militant groups. This conflict was widely attributed to deplorable human security, which deprived the indigenes of the region access to their sources of livelihoods due to pollution, by MNCs. In 2009, the government granted amnesty to thousands of 'repentant militants' and this programme has achieved mixed results. This article will explore the impact of human security on the outbreak of violence in the Niger Delta and the impact of the Amnesty Programme in addressing issues relating to human security. The article concludes that bottom-up community-driven initiatives offer the best approach to address human security issues in the Niger Delta. The article is based on an ethnographic research carried out in 2013 in three states in the region (Bayelsa, Delta and Rivers states).
\end{abstract}

Keywords: Human security, justice, environment, Niger Delta, MNCs

DOI: http://dx.doi.org/10.4314/jsdlp.v7i2.5

\section{INTRODUCTION}

In the last two decades, one of the major areas in Africa affected by violent conflict has been the Niger Delta region of Nigeria. Home to about 20 million Nigerians and located in West Africa's oil-rich Gulf of Guinea, the Niger Delta is strategic to the energy security calculations of the world's established and emerging powers. ${ }^{1}$ Although the oil

* Department of Politics, University of York, email: oaa511@york.ac.uk

1 Elias Courson, 'Movement for the Emancipation of the Niger Delta (MEND): Political Marginalization, Repression and Petro-Insurgency in the Niger Delta' (Nordic Africa Institute, Discussion Paper 47, 2009) <www.diva-portal.org/smash/get/ diva2:280470/FULLTEXT01.pdf> accessed 25 January 2016. 
produced from the Niger Delta accounts for about 95 per cent of Nigeria's foreign exchange earnings and 80 per cent of federal government revenues, incessant violence and disruption to oil exploration have impeded development and human security in the region. Since the discovery of oil in 1956, the region has experienced periods of unrest and violent conflicts. Successive military and democratic governments in the country have tried to find a lasting solution to the volatile situation in the region.

The last attempt by the government to end the conflict was to grant amnesty to 'repentant militants' and re-integrate them into the communities through adequate training and provision of employment, which invariably aims to improve their human security. However, an ethnographic research carried out in the region in 2013 revealed that the amnesty programme was flawed with issues relating to transparency and accountability amongst others. Although the Amnesty Programme reduced the conflict in the region, there has been a change of dynamics in the conflict experienced in the region. The conflict has changed from confrontations between militant groups and security forces to inter/ intra community conflicts while environmental degradation remains an issue negatively impacting the livelihood and human security of the people. These issues, coupled with rising unemployment, have resulted in many young people seeking alternative livelihoods, which sometimes are criminal and dangerous.

The aim of this article is not to repeat existing literature on the causes of conflict in the Niger Delta, as several authors have researched these extensively. ${ }^{2}$ On the contrary, this article seeks to explore why the major conflict resolution initiatives in the region failed. The article suggests that addressing human security concerns through bottom-up development initiatives like adequate community governance remains the most valuable strategy for conflict resolution and sustainable

2 See Joseph Richard, 'Class, State and Prebendal Politics in Nigeria' [1983] 21(3) Journal of Commonwealth and Comparative Politics 24; Renner Michael, Fighting for Survival: Environmental Decline, Social Conflict, and the New Age of Insecurity (New York: W W Norton 1996, 54); Ibrahim Elbadawi and Nicholas Sambanis, 'Why Are There So Many Civil Wars in Africa? Understanding and Preventing Violent Conflict' (2000) 9(3) Journal of African Economy 247; Paul Collier and Anke Hoeffler, 'Greed and Grievance in Civil War' (Oxford University, Centre for the Study of African Economic, 2002) <www.csae.ox.ac.uk/workingpapers/pdfs/20-18text. pdf> accessed 25 January 2016; Augustine Ikelegbe, 'Economy of Conflict in the Oil Rich Niger Delta Region of Nigeria’ [2006] 5(1) African and Asian Studies 27. 
development in the region. After critically exploring the impact of human security on the outbreak of conflict in the region, the article concludes that community-driven initiatives based on accountability and transparency offer the best solutions to peace and stability in the region.

This article is based on empirical evidence from an ethnographic research carried out in the region in 2013 focusing on the three most significant states regarding oil exploration and the outbreak of conflict (Bayelsa, Delta and Rivers states). The study involved 56 in-depth interviews, group interviews, and participant observation over a threemonth period. The interviewees included government officials, MNC staff, local indigenes from 18 communities, non-governmental organizations (NGOs) and civil society groups. Analysis of the interviews was carried out using thematic template analysis.

The first section of the article will analyse the theoretical narratives on the outbreak of conflict in the Niger Delta before critically exploring the issues of human security and its impact on conflict in the region. The second section explores the role of the government, MNCs and indigenes of the Niger Delta in the conflict and subsequent human security challenges in the region. The third section analyses the amnesty granted repentant militants and the impact of the amnesty since inception in 2009. The fourth section of the article critically examines local community governance and the impact of transparency and accountability in local communities and how this has entrenched peace and economic development in communities with improved governance.

\section{HUMAN SECURITY AND THE OUTBREAK OF CONFLICT}

There are several variables that have resulted in the lack of development and the resulting violent conflict in the Niger Delta region of Nigeria, which has impacted negatively on the Human Security of the people. Some of these variables, which have been well researched, include greed ${ }^{3}$ grievance, ${ }^{4}$ predatory governments ${ }^{5}$ and prebenda-

3 Paul Collier and Anke Hoeffler, 'Resource Rents, Governance, and Conflict' (2005) 49(4) Journal of Conflict Resolution 626.

4 Thomas Homer-dixon, Environment, Scarcity and Violence (Princeton, N J: Princeton University Press 1999, 47).

5 Stanley Engerman and Kenneth Sokoloff, 'Factor Endowments, Institutions and Differential Paths to Growth Among New World Economies: A View from Economic Historians in the United States' in Stephen Haber (ed), How Latin America Fell Behind Stanford (Stanford: Stanford University Press 1997, 35). 
lism. ${ }^{6}$ Despite the significance of the region to the economy of Nigeria, sporadic violence has made the region volatile, and several initiatives designed to ameliorate the situation and enhance the human security of the inhabitants have achieved limited success.

According to the 1994 Human Development Report, 'Human Security means that people can exercise their choices safely and freely - and that they can be relatively confident that the opportunities they have today are not totally lost tomorrow'. ${ }^{7}$ The report sees human security from two different perspectives. First, safety from threats such as hunger, disease and repression; second, protection from sudden and hurtful disruptions in the patterns of daily life - whether in their homes, at work or in the communities (freedom from fear and freedom from want). The report states further that when people perceive a threat to their lives, they often become intolerant - just like the case in the Niger Delta region. In a similar vein, the Commission on Human Security (CHS) defines human security as efforts to 'protect the vital core of all human lives in ways that enhance human freedoms and human fulfilments'.

The concept of human security is different from the human development approach because it is centred on the security of individuals as well as the threats they face, such as political repression, identity and various forms of violence; while human development focuses more on the State. ${ }^{9}$ The UNDP report categorized the threats to human security into seven: economic security, food security, health security, environmental security, personal security, community security, and political security. One important thing to note about human security is that threats are interlinked and interconnected, and individuals could face more than one threat. ${ }^{10}$ In the view of MacFarlene and Khong, 'human security is about the freedom from a threat to the core values

6 Joseph Richard, 'Class, State and Prebendal Politics in Nigeria' (1983) 21(3) Journal of Commonwealth and Comparative Politics 21.

7 United Nations Development Programme, Human Development Report (Oxford: Oxford University Press 1994).

8 United Nations, 'Human Security Now' (Final Report of the Commission on Human Security, 2003, 4) <www.un.org/humansecurity/content/humansecurity-now $>$ accessed 25 January 2016.

9 Tadjbakhsh Shahrbanou and AM Chenoy, Human Security: Concepts and Implications (London: Routledge 2007, 72).

10 ibid. 
of human beings, including physical survival, welfare, and identity'. ${ }^{11}$

In the Niger Delta region, environmental pollution has impacted negatively on the livelihoods of the people thereby affecting their human security. The once fertile lands have been destroyed and the rivers, which provided fish both for consumption and sales, have been polluted through oil exploration activities, and this has impacted on the human security of the people. In some cases, a symbiotic relationship between government agencies and MNCs operating in the region has resulted in a lack of adequate law enforcement, especially in regards to environmental laws.

Most social science research into the cause of violent conflicts, especially the popular greed-versus-grievance debate, focus on the structural conditions that increase the risk of conflict rather than the decisions of actors to engage in violent acts. In most cases, these structural conditions are based on the analysis of States and other institutions rather than the concern and needs of individuals. ${ }^{12}$ Previously, issues of human security and violent conflict are treated as separate entities in research, but these two are interrelated. The greed theory is one of the most important theories relating the presence of natural resources to violent conflict. Collier and Hoeffler argued that countries possessing natural resources have more likelihood of experiencing violent conflict arguing further that one of the main factors in any such conflict is greed. ${ }^{13}$

It is important to state that although greed might have surfaced during the crises in the Niger Delta, it was not the initial basis for the

11 Neil Macfarlane and Yuen Foong khong, Human Security and the UN A Critical History (Bloomington, IN: Indiana University Press 2006, 143).

12 See Nils Petter Gleditsch, 'Armed Conflict and the Environment: A Critique of Literature' (1998) 35(3) Journal of Peace Research 388; Alex Bellamy and Matt Mcdonald, "The Utility of Human Security": Which Humans? What Security? A reply to Thomas \& Tow' [2002] 33(3) Security Dialogue 373; Jonathan Goodhand, 'Enduring Disorder and Persistent Poverty: A Review of Linkages Between War and Chronic Poverty' [2003] 31(3) World Development 629; C. Cramer, 'Homo Economicus Goes to War: Methodological Individualism, Rational Choice and the Political Economy of War' [2002] 30(11) World Development 1845.

13 Paul Collier and Anke Hoeffler, 'Greed and Grievance in Civil War' (Oxford University, Centre for the study of African Economic, 2000) <www.csae.ox.ac.uk/ workingpapers/pdfs/20-18text.pdf > accessed 25 January 2016; Paul Collier and Anke Hoeffler, 'Resource Rents, Governance, and Conflict' [2005] 49(4) Journal of Conflict Resolution 635. 
agitation by the people of the region. Although there were incidences of greed perpetuated by some of the advocates in the struggle for resource control, there was a genuine situation of neglect that led to the grievance. Shahrbanou and Chenoy suggest that 'the greed analysis of conflict would plausibly dismiss movements and struggles based on genuine grievances of people that arise out of oppression and violation of rights, which may be morally justified. ${ }^{14}$ They also noted that the greed theory does not adequately point to issues such as the violation of rights, the building of stereotypes and the biased nature of states in dealing with sensitive inter-community matters, especially on issues relating to natural resources. This article focuses on the Niger Delta region's environmental security because it embodies all the other human security issues experienced there.

In many conflicts, the armed groups consist of young men who are frustrated by the contractions in their livelihoods eroding the opportunity of living a better life mostly due to actions that are not perceived to be their faults. ${ }^{15}$ According to Ohlsson, 'the common denominator of many, if not most, of the civil wars and conflicts which plagued Africa, South Asia, and Latin America during the last decade is poverty resulting from loss of livelihoods which, in turn, is often caused or exacerbated by environmental degradation'. ${ }^{16}$ De Soysa et al, explain further that declining access to land as well as a reduction in the returns from the human use of land is a key process that causes livelihood contraction; hence, increasing the risk that people will join armed groups. ${ }^{17}$ In the view of Scheper-Hughes, ${ }^{18}$ the decision of a young man to join an armed gang may be as a result of genuine grievance, frustration, and a desire for revenge, or by identification with a common

14 Shahrbanou and Chenoy (n 9).

15 Leif Ohlsson, 'Livelihood Conflicts: Linking poverty and environment as causes of conflict' (Stockholm: Environmental Policy unit, Swedish International Development Cooperation Agency, 2000) <www.staff.ncl.ac.uk/david.harvey/ AEF806/OhlssonLivelihoods.pdf $>$ accessed 26 January 2016.

16 ibid 3.

17 Indra De soysa, Nils Gleditsch, Michael Gibson and Margareta Sollenberg, 'To cultivate peace: Agriculture in a world of conflict' (Wilson Centre-Environmental Change and Security Project Report 5:15-25, 1999) <www.wilsoncenter.org/ sites/default/files/feature2.pdf> accessed 25 January 2016.

18 Nancy Scheper-hughes, 'Violence in war and peace: An anthology' in Nancy Scheper-hughes and Philippe Bourgois (eds), Who's the killer? Popular Justice and Human Rights in a South African squatter camp (Oxford: Blackwell, 2004) 61. 
cause, a need for protection from violence, and poverty caused by a denial of economic freedoms. ${ }^{19}$ In the Niger Delta region, environmental degradation, coupled with the dearth of an alternative source of livelihood has resulted in unemployment and underemployment in the Niger Delta. Furthermore, poor governance, especially at the community and local government levels, has robbed the region of much needed development. ${ }^{20}$ All these indicate the importance of exploring the perspective of the outbreak of conflict from the lens of human security.

On environmental degradation, the extent and nature of the stresses that people face are determined by the level of dependence on natural resources and ecosystem services as well as the people's capacity to adapt to the changes in these resources. ${ }^{21}$ This indicates that when people directly depend on natural resources for their livelihood, they face immediate risk if there is a change in the balance of these resources. In the Niger Delta region, the traditional occupation of the male inhabitants was farming and fishing while the women engaged in food processing and marketing. The loss of livelihood impacted on the human security of the people, especially the youths which has led to the grievance and a repeated cycle of widespread protests which are 'crushed' by the government resulting in the youths arming themselves to either attack security forces or oil installations. This interplay between environmental degradation, human security and violent conflicts in the Niger Delta is worth exploring further.

\section{HUMAN SECURITY: GOVERNMENT, MNCs AND LOCAL COMIMUNITIES}

Many studies have heaped the blame for the conflict in the Niger Delta on the Nigerian government and MNCs operating in the region. According to World Organization against Torture (OMCT), in the first

19 Musifiky Mwanasali, 'The view from below' in Mats Berdal and David Malone (eds), Greed and Grievance: Economic Agendas in Civil Wars (Boulder, CO: Lynne Rienner 2000, 137).

20 United Nations Development Progamme, Niger Delta Human Development Report (UNDP Nigeria, 2006).

21 Jon Barnett and W. Adger, 'Environmental change, human security, and violent conflict' in Global Environmental Change and Human Security (MIT Press Cambridge, Massachusetts 2010) 4. 
three years of Nigeria returning to democracy after 1999, over 50 incidences of conflict were recorded resulting in the death of more than 10,000 Nigerians. Several hundreds of thousands of people were reportedly displaced as a result of the violence. ${ }^{22}$ The report stated further that security agents carried out most of the killings with orders from the government. The role of the State in fuelling violence in the country includes: (1) The inability of the government to bring the perpetrators of the violence to book often because, in most cases, the people responsible for these acts are either top government officials or people that help the government win elections (political godfathers); (2) State sponsored vengeful attacks by soldiers after attacks on security forces, examples include the Odi massacre which resulted in the death of 2,483 people ${ }^{23}$ and the Baga massacre where 228 people were killed; (3) Collusion of government officers either by taking sides or simply refusing to act; for example, there was an allegation against a former defence minister during the Tiv/Jukun crises that he aided the Jukuns by supplying them with military uniforms and weapons because they were his kinsmen; (4) Reckless territorial demarcation and the allocation of local governments without consultation and based on political manipulations. As exemplified in the Warri crises of 1997, governments create conflict by manipulating the people's ethnic sensibilities and political authority. ${ }^{24}$

Furthermore, the Nigerian state often condones militant activities. The three major ethnic groups comprising 50 per cent of the population have ethnic pseudo-militias they identify with, such as Arewa (HausaFulani), Bakassi boys (Igbo), Oodua People's Congress (Yoruba) and

22 World organization against torture, 'Hope Betrayed: A report on Impunity and State Sponsored Violence in Nigeria' (OMCT, 2002) < www.omct.org/files/ 2002/09/1231/nigeriareport0802.pdf > accessed 27 January 2016.

23 Environmental rights action, 'A Blanket of Silence, Images of the Odi Genocide' (Environmental Rights Action (Friends of the Earth) 2002) <www.eraction.org/publications/silence.pdf> accessed 25 January 2016.

24 Leton Marcus, 'Oil and the Urban Question: Fuelling Violence and Politics in Warri, Niger Delta' (Economies of Violence, Working Paper 8, Berkeley University, 2006) 10 <http://geog.berkeley.edu/ProjectsResources/ND\%20Website/ NigerDelta/WP/8-Leton.pdf $>$ accessed 25 January 2016; Victor Ojakorotu and Ufo Okeke-uzodike, 'Oil, Arms Proliferation and Conflict in the Niger Delta of Nigeria' (2006) 6(2) African Journal on Conflict Resolution 85. 
the Consultative Forum. ${ }^{25}$ The perceived injustice felt by the ethnic minority groups especially those from the Niger Delta, coupled with their feeling of marginalization despite producing most of the country's resources is partly responsible for the formation of their own militant groups which are also formed along ethnic identities to 'defend their rights' ${ }^{26}$ The complacency of the Nigerian state in this regard is the failure to curtail the creation of these groups. In an interview, an exmilitant said since government failed to curtail the activities of the militias representing the bigger ethnic groups, it has no justification to proscribe those in the Niger Delta. The respondent also rejected the term 'militia' but argued that they are 'freedom fighters' and ${ }^{27}$ many of the region's clashes are between these rival ethnic militias. Guichaoua described the militias in Nigeria as insurgent groups mostly defending causes 'aligned with ethnic interests'. ${ }^{28}$

The advent of democracy in Nigeria brought little succour. The militias in Nigeria are entrenched in the electoral system being used by politicians to advance selfish ambitions by intimidating voters and harassing political opponents, ${ }^{29}$ which explain the ruling elites' reluctance to prohibit the groups. Newsom observes that the cycle of violent conflict in the Niger-Delta has been tied to elections ${ }^{30}$ evidenced by the increase in violence shortly before and after elections, especially the 2003 and 2007 elections. Shortly before these elections, some politicians in Nigeria imported large quantities of arms and ammunitions. ${ }^{31}$ Young people, who are mostly jobless, are then

25 Yvan Guichaoua, 'How Do Ethnic Militias Perpetuate in Nigeria? A Micro-level Perspective on the Oodua People's Congress' (2010) 38(11) World Development 1664.

26 ibid 7.

27 Interview in Rivers state, September 2013.

28 ibid.

29. Human rights watch, Nigeria's 2003 Elections: The Unacknowledged Violence (Washington: Human Rights Watch 2003a, 11); Human rights watch, Criminal Politics: Violence, 'Godfathers' and Corruption in Nigeria (Washington: Human Rights Watch 2007, 33)

30 Chris Newsom, 'Conflict in the Niger Delta, More than a Local Affair' (United States Institute of Peace special report 217, 2011, 1) <www.usip.org/files/ resources/Conflict_Niger_Delta.pdf $>$ accessed 26 January 2016.

31 Ebere Onwudiwe and Chloe Berwind Dart, 'Breaking the Cycle of Electoral Violence in Nigeria' $(2010,4)$ United States Institute of Peace < http:// www.usip.org/sites/default/files/resources/SR263-Breaking_the_Cycle_of_ Electoral_Violence_in_Nigeria.pdf > accessed 17 March 2016. 
recruited to intimidate voters and rig elections. The politicians who are unable to retrieve the weapons from them then discard them after the elections. Subsequently, they form their own militant groups and begin to bomb economic infrastructure to gain significance after which they move on to hostage taking and kidnapping using these same weapons. ${ }^{32}$

Another complicit actor is the MNCs operating in the region accused of negligence resulting in environmental pollution in the region. The United Nations Environmental Programme (UNEP) has carried out the most comprehensive analysis of the extent of pollution in the Niger Delta in 2011. Both local and international experts who surveyed 122km of pipelines, 4,000 samples of soil and water from different areas and sources, 5000 medical records and held 264 meetings attended by over 23,000 people in the region carried out the project. ${ }^{33}$ Although most of the MNCs claim that they operate at the highest standards in Nigeria and that international practices are observed during their operations, the report proved otherwise. The UNEP report blamed the MNCs for negligence and oil pollution in the region.

Furthermore, the system of compensation used by the MNCs for lands used for oil exploration referred to as 'operation techniques' by staff but often labelled as 'divide and rule' by the communities sometimes results in violent conflicts and several respondents (including senior MNC and government officials) agreed. Also, MNC staff historically introduced pipeline vandalization. A senior government official explained that in the 1980s, Shell had some workers called 'damage clerks' whose responsibility was to travel round the operations areas of Shell and report leaks or pipeline damages. The damage clerks were also responsible for evaluating the extent of damage to farmlands and process farmers' claims. After sometime, the damage clerks began to teach locals how to identify pipelines for vandalization in order to make claims, thus starting a trend.

32 Chris Newsom, 'Conflict in the Niger Delta: More than a Local Affair' (2011) United States Institute of Peace' <http://www.usip.org/sites/default/files/ resources/Conflict_Niger_Delta.pdf $>$ accessed 17 March 2016.

33 United Nations Environmental Programme (UNEP)' Environmental Assessment of Ogoniland Report $(2011,6)$. Available at <www.unep.org/disasters andconflicts/CountryOperations/Nigeria/EnvironmentalAssessmentof Ogonilandreport/tabid/54419/Default.aspx> accessed 13 March 2016. 
On the other hand, several indigenes of the region are equally complicit. Some youths in the region have used the excuse of lack of adequate employment to engage in oil bunkering and pipeline vandalization. This has further impacted on the environment, impeding the human security of the inhabitants of the region.

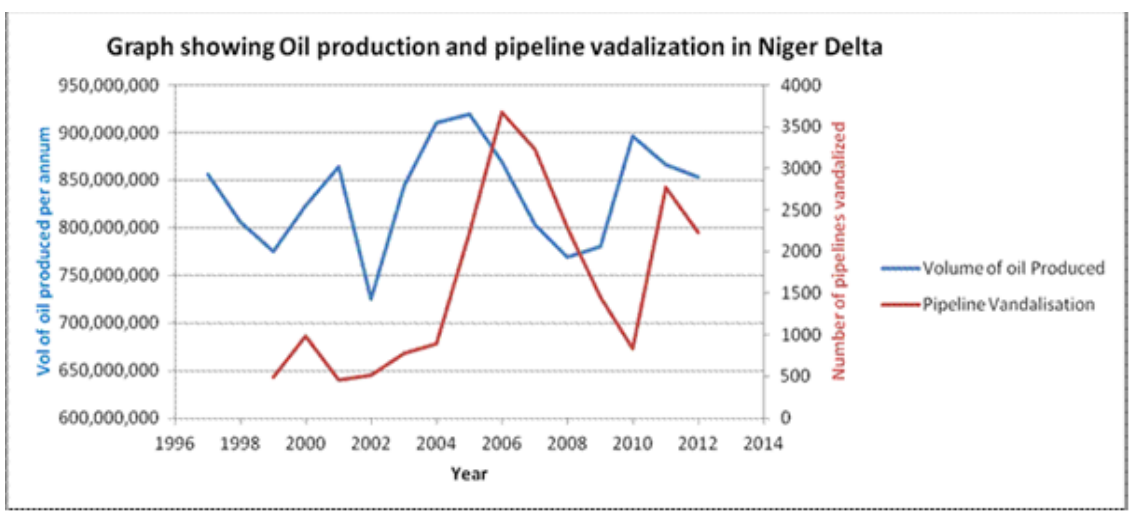

Figure 1: Oil Production and Pipeline Vandalization in the Niger Delta Source: Nigeria National Petroleum Commission Database)

Figure 1 shows the number of pipelines vandalized since 1999. It is important to note that pipeline vandalism reduced drastically in 2010 (a year after the start of the Amnesty Programme) but spiralled again the following year. A new trend of vandalism in the region emerged recently, which I term 'Vandalization for Attention'. In several communities I visited in 2013, many youths attested to participating in pipeline vandalism not because they are interested in siphoning crude oil for sale but to attract the attention of the MNCs and invite them for dialogue. They argued that it is a 'potent weapon' as the MNCs only respond when their production is disrupted, implying that the environment is further and deliberately polluted by a segment of the victims. And human insecurities increases while youths rival youths engaged in oil bunkering clash and have confrontations with security forces.

\section{AMNESTY FOR 'REPENTANT MILITANTS: THE WAY FORWARD?}

In 2008, the government set up a Technical Committee on the Resolution of Niger Delta Crises (TCRND). The purpose of the 
committee was to study the recommendations of previous commissions and make recommendations on how to achieve sustainable development, peace as well as human and environmental security in the region. Previous commissions included the Sir Henry Willinks Commission Report on the Fears of the Minorities (1958); General Alexander Ogomudia's Special Security Committee Report on Oil Producing Areas (2001); and the Report of the National Political Reform Conference (2005) among others. ${ }^{34}$ The TCRND, made up of 44 members with 'extensive knowledge' of the Niger Delta, came up with several recommendations, including increasing the revenue allocation to 25 per cent in the interim and later to 50 per cent (the allocation stands at 13 per cent at time of writing); establishment of a Disarmament, Decommission and Reintegration (DDR) Commission which will address the challenge of arms and militancy; negotiate amnesty for all Niger Delta militants; end gas flaring by December 2008; generate 5,000MW of power for the Region by 2010, and ensure significant improvement in education, health and youth employment in the region. ${ }^{35}$

Of all the recommendations of the technical committee, the federal government only pursued two: amnesty for militants and the establishment of a DDR Commission to pave the way for the amnesty process. ${ }^{36}$ In August 2009, the government granted an amnesty deal to 20,192 registered militants with an initial budget of N52 billion (US\$145 million). ${ }^{37}$ Between July and August 2009, thousands of the repentant militants surrendered thousands of weapons, including gunboats, automatic rifles, rocket-propelled grenades, ammunitions, bulletproof vests, etc. ${ }^{38}$ However, the militants did not surrender their entire arsenal because of the lack of trust in the government and the Amnesty Programme. An ex-militant interviewed stated that many of

34 SDN, 'The Report of the Technical Committee on the Niger Delta' (Stakeholder Democracy Network, 2008, 14) <www.stakeholderdemocracy.org/uploads/ Other\%20publications/Nigeriareport.pdf> accessed 25 March 2014.

35 ibid.

36 ibid.

37 Daniel Agbiboa, 'Have we heard the last? Oil, environmental insecurity, and the impact of the amnesty programme on the Niger Delta resistance movement' (2013) 40(137) Review of African Political Economy 454.

38 Peterside Joab, 'State and Fallacy of Rehabilitation of Repentant Militants' in Nigeria's Niger Delta: Analysis of First Phase of the Federal Government's Amnesty Program' (2010) 11(4) Pan African Social Science Review 69. 
the militant groups did not trust the government to deliver on their promises based on previously broken accords and feared that the government could militarize the region again afterwards. ${ }^{39}$

Furthermore, the Amnesty Programme has been described as a sham, not intended for the development of the Niger Delta but to stop the militants from fighting and destroying oil infrastructure, which cripples oil exploration. ${ }^{40}$ The region remains underdeveloped; oil pollution and gas flaring have continued and the poverty rate is very high. Despite the TCRND recommendation that all gas flaring activities must end by December 2008, there were still dozens of visible gas flaring activities taking place in 2013. A Project Officer of Environmental Rights Action stated during an interview that oil pollution as a result of equipment failure remains prevalent in the region. In 2007, Al Jazeera correspondents visited some communities in the Niger Delta and reported the prevalent poverty and environmental degradation in the region. Eight years after (2015), the same communities were visited again, and the report confirmed that nothing has changed and bunkering has increased in some of the communities. ${ }^{41}$

Reviewing the TCRND recommendations show that several are yet to be implemented. The Amnesty Programme, adopted as a 'quick fix', has succeeded to an extent in reducing the conflict in the region and allowed the MNCs to increase productivity. It is arguable that the reduction in pipeline vandalization (Figure 1) in 2010 was a direct response to the adoption of the Amnesty Programme. A surge in pipeline vandalism in 2011 shows that the menace is on the rise again, and indepth interviews in the three case study states revealed that the Amnesty Programme succeeded in solving the short-term problem of confrontations between militants and security forces but shifted the attention of the youths to other vices such as oil bunkering and vandalization for attention.

The Amnesty Programme failed to consider women, children and the elderly who also bear the brunt of human insecurity in the region while a large percentage of the youths trained as part of the Amnesty Programme remain unemployed and deep rooted issues such as

39 Interview in Bayelsa, September 2013.

40 Daniel Agbiboa (n 37).

41 Al Jazeera, 'Poverty Persists in The Niger Delta' (2015) < http:// www.aljazeera.com/news/africa/ 2015/03/nigeria-poverty-niger-delta150305014819233.html> accessed 13 March 2016. 
marginalization and environmental degradation remain unaddressed. ${ }^{42}$ The survival of the State has been prioritized ahead of its citizen's survival, ${ }^{43}$ and the Nigerian state has prioritized oil production in the Niger Delta at the expense of the people.

\section{THE IMPACT OF GOVERNANCE, TRANSPARENCY AND ACCOUNTABILITY ON LOCAL COMIMUNITIES}

Although several studies ${ }^{44}$ portray the Nigerian government and the MNCs as the culprits while the indigenes of the local communities as victims, it is important to state that the indigenes are also culpable. With actions ranging from vandalization for attention, to kidnapping and harassment of oil workers, it is clear that local communities are part of the crises. One major reason for the volatile nature of the region is the breakdown of community structures, especially regarding leadership. The 2009 amnesty created a change in dynamics in the conflict shifting the interplay of the conflict from security forces versus local communities/militants to inter/intra community conflict.

Most of the conflicts now experienced in the region have been as a result of lack of accountability of community leaders; community leadership tussles and clashes among youths involved in oil bunkering. There have been cases where community leaders embezzled funds meant for community projects leading to clashes between the supporters of such leaders and their opponents. Many youth organisations looked inward and realized that the governance of the distribution of the resources is a major problem. ${ }^{45}$ To address the

42 Oluwatoyin Oluwaniyi, 'Post Amnesty Programme in the Niger Delta: Challenges and Prospects' African Centre for the Constructive Resolution of Disputes (ACCORD) 2011; Moses Ikoh and Ebebe Ukpong, 'The Niger Delta Crises: Taming Violence Beyond the Amnesty' 2013 (3)7, International Journal of Humanities and Social Sciences 152.

43 David Bosold, 'Development of the human security field' in David Chandler and Nik Hynek (eds), Critical Perspectives on Human Security (Abingdon: Routledge 2011) 36.

44 Ike Okonta and Oronto Douglas, 'Where Vultures feast: Shell, Human Rights and Oil', (2003) London, Verso.

45 Darlington Ashamole, 'Youth, Masculinity and Intergenerational Conflict: Investigating the Crisis between Niger Delta Youth and Elders from Gender Perspective' (PhD thesis submitted to the University of Sheffield, United Kingdom, 2014). 
problem, the youths have engaged in several vicious attacks against their leaders leading to the death of many elders in the region. ${ }^{46} \mathrm{~A}$ community leader interviewed in Bayelsa State stated that 'although we blame the government and MNCs for our woes, sometimes we are the architects of our own misfortune. The leaders have been corrupted and, in several cases, they steal the little resources that accrue to the community. Such leaders have turned themselves into godfathers using our children against us and creating division in the communities'. ${ }^{47}$ In order to curtail this trend of inter/intra community conflicts caused by inadequate governance at the community level, some of the MNCs operating in the region embarked on initiatives to improve transparency and accountability as well as enhance the governance of the distribution of resources in local communities. This section will explore two of such initiatives and their impact in boosting domestic economic transformations in several communities in the Niger Delta.

\section{COMMUNITY-DRIVEN DEVELOPMENT APPROACH: THE AKASSA MODEL}

The perceived failure of the development approach in use, coupled with an increase in oil- related violence led to the development of a different model of resource distribution by Statoil piloted in 1997 across 19 communities where the company operates. ${ }^{48}$ The new community development model involved all the 19 communities contributing to the drafting of a development plan, which was submitted to Statoil for implementation. The first stage was the merging of all existing community development groups such as the council of elders, the women groups, and the youth groups to form a single community development group called Akassa Development Foundation (ADF). Every year, the ADF designs a community development plan, which is entirely funded by Statoil. The plan is based on consultation from several organizations within the participating communities. A distinguishing aspect of the model is that community members suggest projects.

46 ibid.

47 Interview in Bayelsa state, September 2013.

48 Statoil, 'Akassa Model Website' (Statoil Local Value, 2014) <www.statoil.com/ en/Environment Society/Sustainability/Pages/LocalValue.aspx $>$ accessed 27 January 2016. 
The model is entirely bottom-up with the ADF involved at every stage of the development of the model. An evaluation of the model in 2014 by Kimenyi et al. suggests that the Akassa model is a successful community development model due to three main reasons. First, community members are involved in project design and implementation, second, the community members are involved in setting the goals of the ADF and, third, community members are involved in discussing and approving the rules of the projects with little or no interference. ${ }^{49}$ Furthermore, Kimenyi et al. explained that the model exhibits good community governance through transparency and accountability and this has positively impacted on the human security of the people living in these communities. There are provisions of basic infrastructure such as water, electricity and health centres and many of the youths have been empowered, through the initiatives developed by the model. In addition to these, the model consists of an excellent conflict resolution mechanism, which has helped in resolving disputes between the communities. Available data from the NNPC indicate that there is a low prevalence of pipeline vandalization in the Akassa communities. This analysis indicates that the Akassa model has considerably addressed issues relating to human security in the communities involved.

Although the Akassa model has been described as an efficient bottom-up community-driven resource distribution model in the Niger Delta, the replication of the model is debatable for three main reasons. First, the model is used in only 19 communities in the Niger Delta. Considering that there are over 3000 communities in the region, it is difficult to see how the model can be replicated. Second, all the communities are located offshore. Hence, it is important to consider a model that can also be applicable onshore. Third, Statoil is a relatively small company with less than two per cent of the total oil production in the Niger Delta. Despite these issues, the bottom-up approach to development used by Statoil has yielded positive dividends.

49 Mwangi Kimenyi and others, Analysis of Community-Driven Development in Nigeria's Niger Delta Region: Use of the Institutional Analysis and Development (Iad) Framework (African Growth Initiative: Brookings 2014, 22); Uwafiokun Idemudia, 'Oil extraction and poverty reduction in the Niger Delta: A critical examination of partnership initiatives' (2009) 90(4) Journal of Business Ethics 91; Olubayo Oluduro and Olubisi Oluduro, 'Nigeria: In search of sustainable peace in the Niger Delta through the Amnesty Programme' (2012) 5(7) Journal of Sustainable Development, 52. 


\section{CHEVRON GLOBAL MEMORANDUM OF UNDERSTANDING (GMOU) MODEL}

According to Haider, to develop a holistic approach to peace building in a region ravaged by violent conflict, it is important to address both the tangible and intangible effects of the conflict. ${ }^{50}$ The tangible effects are the visible aspects of the conflict such as environmental insecurity, and destruction to infrastructure, the people killed or wounded during the conflicts as well as disruption to the sources of livelihoods of the people. The intangible aspect includes the collapse of community structure, the fear and trauma experienced by the people during the crises, lack of trust in government, state institutions and the MNCs, as well as the psychological effects associated with the loss of livelihoods. In any conflict situation, violence transforms both the social and political foundations of the community, and this makes it imperative to develop a 'community-oriented analytical approach', which should help understand how communities re-emerge and organize despite the challenges involved. ${ }^{51}$

In many of the peace initiatives set up either by the government or the MNCs, the communities are often left behind and when the communities are involved, it is limited to a few influential people or godfathers who mostly do not have the interest of the populace in mind. ${ }^{52}$ Furthermore, development initiatives often go through third parties and not directly to the communities. An increase in awareness in the local communities coupled with the emergence of several youth groups has made it increasingly difficult for a few influential people or the so-called godfathers to maintain a grip on the increasingly volatile communities. ${ }^{53}$ This implies that any peace process to be initiated must involve the full acceptance of all the stakeholders, especially the community members. Such peace process must also go directly to the

50 Huma Haider, 'Community based Approaches to Peacebuilding in Conflict affected and Fragile Contexts' (Governance and Social Development Resource Centre (GSDRC), 2009) <www.gsdrc.org/docs/open/eirs8.pdf> accessed 27 January 2016.

51 Béatrice Pouligny, 'Civil Society and Post-Conflict Peacebuilding: Ambiguities of International Programmes Aimed at Building "New" Societies' (2005) 36(4) Security Dialogue 499.

52 Interview with Environmental Rights Action project officer Delta state, August 2013.

53 Ashamole (n 45) 126. 
communities involved with little or no interference from third parties.

Given this, Chevron, together with some NGOs, developed a new sustainable approach to development in 2005 for use in all its areas of operation. Called the Global Memorandum of Understanding (GMOU), this model gives the communities greater roles in determining how and what should be done regarding their development. The company decided to change its resource distribution method by dealing with the communities directly through committees selected by the community members. The main objective of the initiative was to ensure peace and stability in the areas, as well as, understand the agitations of the people and try to find solutions to them. ${ }^{54}$

The GMOU model was designed to address most of the challenges faced by Chevron while operating in the communities. The model that was only used in Nigeria by Chevron (at the time of writing - 2016) is a bottom-up approach where the communities are given the privilege of deciding the projects to be done in their communities based on the needs of the people. Before the GMOU process, the oil companies hired development experts to analyse the situation in each community and send the analysis to the company's community development units (CDU). The CDU, in conjunction with some influential members of the communities, then designed the projects which were often carried out by selected community members (often the godfathers) ${ }^{55}$ or companies owned by friends of the CDU members which were not even affiliated with the communities.

The GMOU process was rolled out in 2006, but it was not fully operational until 2009, a period that coincided with the start of the Amnesty Programme. Although the effect of the amnesty on the model is not entirely clear, a senior manager interviewed at Chevron in August 2013 stated that the Amnesty Programme made it easier to roll out the project in more communities. The GMOU is a shift from patronagebased to technocratic means of community development based on a bottom-up approach. The process is clear and transparent and although it is still undergoing a 'refining' stage and the process can be improved

54 Chevron, 'Nigeria: In the community' (Chevron Nigeria, 2014) $<$ www.chevron.com/countries/nigeria/inthecommunity/> accessed 27 January 2016.

55 'Godfather' is a term used for influential people in the community who often use force or violence to achieve their aims and are sometimes perceived to be above the law. 
significantly, it has been commended by many of the stakeholders in the region as the most impactful as far as community development is concerned. ${ }^{56}$

The model's first significant change is in the governance structure of the communities. All the communities where Chevron operates were divided into eight regional development councils (RDCs), which are along ethnic lines. The represented communities elect the representatives of each $\mathrm{RDC}$, and this limits the agitation for leadership in the communities. Second, there is transparency in the allocation of resources by Chevron, which is then replicated by a transparent bidding process for contracts awarded in the communities. Third, there is accountability at every stage of the process. Chevron pays directly into selected banks, which act as trustees for the funds. The bank release funds to contractors in trenches only after all the parties agree that the previous allocation has been judiciously spent. There are representatives of Chevron, NGOs, government, banks and local communities in the governing council of the Community Engagement Management Board (CEMB) - the body created to supervise all the eight RDCs.

In all, 16 out of 20 respondents from communities in Chevron's operational areas expressed satisfaction with the standard of governance, accountability and transparency in the new GMOU model. Most of the respondents agreed that the model had reduced violent agitations in the communities thereby boosting local economy while greatly reducing the influence of godfathers and creating employment through the use of indigenous contractors. One of the managers interviewed in September 2013 stated that Chevron had witnessed significantly reduced disruption in its areas of operations. There is a peace and reconciliation committee in each RDC and communities that record zero pipeline vandalization are given an annual bonus. Furthermore, analysis of NNPC data on pipeline vandalization reveals that there has been a reduction in pipeline vandalization in communities where Chevron has implemented the GMOU model. Some of the visible projects completed in the RDCs visited include community health centres, primary and secondary schools and skills acquisition centres. Some of the RDCs also have soft loans for people interested in setting up small- and medium-scale businesses. This model has invariably positively impacted on the human security of the communities where Chevron operates.

56 Interview with stakeholders in the Niger Delta, August 2013. 


\section{COMMUNITY DEVELOPMENT IN THE NIGER DELTA: LEGAL PERSPECTIVES}

It is evident that the Nigerian government and the MNCs have made some attempts to develop the Niger Delta and reduce the conflict that has ravaged the region. The question is how appropriate these initiatives are in addressing the challenges faced by this region. Following the recommendations made by the TCRND, the resulting disarmament and amnesty granted to repentant militants, without the implementation of the other recommendations show that the government is interested only in short-term measures neglecting the long-standing issues. Furthermore, development agencies created for the improvement of the region have failed due to issues relating to corruption and lack of adequate funding. ${ }^{57}$

In addition, there are several legal loopholes about development, oil exploration, and environmental pollution. There is a need for an overhaul of the laws governing oil exploration and community development as well as the structures for law enforcement. ${ }^{58}$ Despite government's enactment of several laws to prohibit environmental degradation and adherence to best practices, there are inadequate facilities for law enforcement. The implication of this is that the MNCs sometimes operate with impunity and utter disregard for the environment.

It is the responsibility of the Nigerian government to promote and protect the economy of the Niger Delta as well as provide amenities that will enhance the development of the region, thereby enhancing the human security of the people. To promote and protect the economy of the region, Ogbonnaya argues that existing laws and loopholes in the region must be reviewed. Although there are laws governing issues such as oil exploration activities, environmental degradation, compensation for lands used for exploration as well as other exploration and distribution activities, there is no adequate legal framework for either community development or conflict resolution and law enforcement in the region.

57 Shola Omotola, 'From the OMPADEC to NDDC: an Assessment of State Responses to Environmental Insecurities in the Niger Delta, Nigeria' (2007) 54, Africa Today 582.

58 Ufiem Ognonnaya, 'Environmental Law and Underdevelopment in the Niger Delta Region of Nigeria, [2011] 5(5) African Research Review, 74. 
The three categories of respondents (the government, MNCs and indigenes of oil producing communities) agreed that the lack of an adequate legal structure for the distribution of resources as well as community development creates confusion in the region. The MNCs use their discretion to implement an 'adequate' level of community development, but there is no law that dictates what is adequate. As promising as the Statoil and GMOU models look, the lack of legal obligations makes the future of such models bleak. Although the Petroleum Industries Bill (PIB) proposes an establishment of Petroleum Host Community Fund 'PHC Fund' which should be used for the development of oil producing areas, ${ }^{59}$ the experience of the inadequacies of previous development agencies and funds show that without a clearly spelt out legal understanding of such initiatives, there is little chance of any success.

To achieve sustainable development in the Niger Delta, there are certain structures that must be put in place. First, any development approach must focus not only on short-term initiatives but also on the long-term issues and include all segments of the communities (not limited to the youths). Second, development approaches must be bottom-up with active participation and involvement of the community members. The Akassa and GMOU models show that such strategies would yield more positive results. Third, there is a need to overhaul the legal framework governing oil exploration, community development, and environmental degradation as well as create greater access to justice by empowering magistrate courts which are closer to the people. Furthermore, clear structures for law enforcement are necessary to achieve sustainable development and human security.

\section{CONCLUSION}

The Niger Delta region of Nigeria has experienced several challenges that have impacted negatively on the human security of inhabitants of the region. Nseabasi argues that environmental issues such as pollution and destruction of farmlands and fishponds which serve as the sources of livelihood of people can result in stress that impact on the human

59 NNPC, 'The Petroleum Industry Bill' Nigeria National Petroleum Commission, $<$ http://www.nnpcgroup. com/PetroleumIndustryBill.aspx > Accessed 17 March 2016. 
security of the people and often leads to rebellion. ${ }^{60}$ This is the case in the Niger Delta where rebellion through riots and protests has metamorphosed into the formation of militant groups. Poverty, lack of basic infrastructure and underdevelopment are some of the factors that have led to grievances and also serve as a justification for young men in this region to join militant groups. The feeling of marginalization coupled with the notion that the only 'language' authorities understand is violence also fuels the insurgencies experienced in this region.

Some previous studies carried out in the region have solely put the blame of the conflict on the Nigerian State and the MNCs operating in the region. This article, however, has shown that the indigenes of the Niger Delta are also culpable in the conflict. Trends in environmental degradation such as destruction of oil installations as a panacea to dialogue with the MNCs, including the recent blowing up of pipelines to protest the trial of an ex-militant leader (Government EkpemupoloTompolo), provide further evidence of their culpability. ${ }^{61}$ Issues, such as a breakdown in local community governance, lack of transparency and accountability has shifted the dynamics of the conflict since the inception of the Amnesty Programme. There are fewer confrontations between security forces and communities/militants but more inter/ intra community violence based on issues relating to the distribution of resources.

The youth-focused Amnesty Programme has succeeded to some extent in reducing violent confrontations with security forces. However, the problems of inter/intra community violence, oil bunkering, and pipeline vandalization have been on the increase. Some MNCs have also changed their development approaches and started playing significant roles in the organization of community structures in their areas of operation. Such examples are the case studies of Statoil and Chevron who have developed structures to improve the governance of distribution of resources, thereby reducing conflicts. Despite the success

60 Akpan Nseabasi, 'Governance and Communal Conflicts in a Post-democratic Nigeria: A Case of the Oil-producing Niger Delta Region' (2010) 2(3) Journal of African Studies and Development, 70.

61 Sahara reporters, 'Ex-Militant Leader Fingers Tompolo And Shoot At Sight In Bombing of Delta State Pipelines' (Sahara Reporters, New York, 26 January 2016) <http://saharareporters.com/2016/01/26/ex-militant-leaderfingers-tompolo-and-shoot-sight-bombing-delta-state-pipelines $>$ accessed 27 January 2016. 
of these programmes, the lack of an adequate legal framework to aid such initiatives and the inability of the government to set a defined structure for the development of the region pose a threat to the future of the region as well as the human security of the people.

Although these structures have been adjudged to increase accountability and transparency in such communities, a possible implication of these structures is that it can further reduce the legitimacy of the local governments in the region as the MNCs take on more visible and direct roles in improving the human security of the communities. To achieve sustainable development in the Niger Delta region, there is a need for all the stakeholders involved such as the government, MNCs, indigenes and NGOs operating in the region to agree on a proper bottomup development framework involving the full participation of the indigenes and backed up with a strong legal framework. Furthermore, there is a need to focus on long-term development initiatives that would ensure a secured future for the children in the region. This makes it imperative to increase funding for education and apprenticeships with an emphasis on opportunities in the non-oil sector. 